cools down the burning mass, and itself becomes heated in the process, whilst the carbon dioxide expelled from the water by the heat displaces the atmospheric oxygen in the immediate neighbourhood, and both causes combine to stop the combustion. The larger extinguishers such as are usually supplied to public buildings are of this kind. They contain, typically, a strong solution of sodium carbonate and a charge of hydrocinloric or sulphuric acid. The acid is kept separated from the carbonate until the apparatus is wanted for use, when by means of a breaking or overturning device the acid is mixed with the solution, and immediately liberates the carbon dioxide. The pressure of the gas forces the solution out of the apparatus, just as in the action of an ordinary "syphon" of soda-water.

Other aqueous solutions, frequently used in small extinguishers of the hand grenade type, contain chlorides instead of carbon dioxide. Apart from the water, these are considered to act as fire-quenchers partly by producing extinctive gases, and partly by coating the burning material with a non-combustible film. One formula for such a grenade, for instance, contains common salt and sal-ammoniac, another includes calcium and sodium chlorides, others contain chlorides of calcium and magnesium. Of similar type, too, are some preparations containing sulphites. Thus a solution of sodium sulphite and sal-ammoniac acts as a fire-extinguisher partly by giving off ammonia and sulphur dioxide, partly by the cooling effect of the water, and partly by coating the burning material with sodium chloride.

Of these small extinguishers it may be said in general that for quenching incipient small fires indoors they are useful, but too much should not be expected of them. The quantity of solution in a single extinguisher, or in half a dozen, is too small to be effective unless the fire is of quite restricted dimensions. Much of the quenching effect, it must be borne in mind, is due to the water; and though the chemicals enhance this effect, they do not multiply it to an unlimited degree.

For use more particularly in putting out fires of burning liquids such as petrol, kerosene, and other mineral and vegetable oils, which float upon the surface of water and so may be spread by the latter, extinguishers containing dry powders are sold, and also others composed of non-aqueous liquids. The powders generally include carbonates or bicarbonates, with or without an admixture of chlorides. One much advertised article, for example, consists of a mixture of calcium carbonate and sodium bicarbonate. Their action depends chiefly upon the evolution of carbon dioxide and other gases, under the influence of heat. Like the hand grenade class, these extinguishers are in general effective only with small fires, and not in all circumstances. For example, a film of burning liquid might be extinguished readily by a covering of one of these powders, whereas the powder thrown on a thick layer of the liquid might fall to the bottom and remain practically unaffected, at least until the oil had burnt down to its level.

Of the non-aqueous liquids employed the chief appear to be chlorinated hydrocarbons. They are probably mixtures of several members, but approximate more or less closely to tetrachloroethane, or to mixtures of this with carbon tetrachloride. These depend for their effect upon the production of extinctive gases when heated, and one disadvantage of their employment is the evolution of fumes, copious and unpleasant, consisting of hydrogen chloride. For use on small petrol fires, and also on small quantities of ignited inflammable materials, such as celluloid and carbon bisulphide, they appear to be reasonably efficacious. For larger fires, especially of loose combustible substances such as straw, paper, shavings, and the like, they are of much less value. Extinguishers of this class have thus a special and limited usefulness rather than general applicability to ordinary conflagrations. In fact with these as with all extinguishers, it is well to remember that whilst the prompt application to a small incipient fire may be effective, it is quite another matter when a big blaze has been allowed to develop.

\section{THE SURGERY OF THE WAR.}

WE are familiar, by this time, with the saying that the War has brought "Listerism" back for the treatment of our wounded. Not that the use of antiseptics had ever vanished out of practice: but the aseptic method-the sterilising, by heat, of almost every appliance of surgeryhad come into general use, and had been reckoned as a great improvement on the antiseptic method. It had seemed a safer, more natural, more scientific way of operating. And in civil practice it is, indeed, well-nigh perfect. It is " the ideal method." That is to say, it would be perfect if all surgeons, nurses, and patients were perfect. But it is not so simple as it sounds : and some surgeons, perhaps, have so admired the pursuit of the ideal that they have been tempted to think of Lister's work as a mere "stage" on the way to their own. Then came the War; and, at once, surgeons had to face a condition of wounds very different from the clean-cut incisions made in the formal operations at placid, well-appointed hospitals and nursinghomes over here. This overwhelming multitude of shell-wounds and shrapnel-wounds, infected right away with mud and sweat and particles of clothing, and with all the germs of heavily manured soil, must be disinfected, if that were possible, with antiseptics. Thus, there has been that return to the antiseptic method which Sir Rickman Godlee described, a few months ago, in his lecture at the Royal Institution.

But this return to Listerism reminds us of Mme. de Staël's wise saying, "L'esprit humain fait progrès toujours, mais c'est progrès en spirale." If we are indeed back at Lister, we are back at a higher level. It is exactly half-a-century since he, in Glasgow, in 1865 , first plugged the wound of

$$
\text { No. 2386, vOL. 95] }
$$


a compound fracture with a strip of linen soaked in coarse, impure, undiluted carbolic acid. What came of that experiment the world knows, and is not yet tired of knowing. But he could not then foresee the wealth of new discoveries which followed, incessantly, this first method of dealing with "germs of putrefaction." Least of all could he foresee the swift rise of bacteriology, its extension over the whole art and science of medicine and surgery, and its magnificent achievement of protective treatments, antitoxins, and vaccines. But he lived to see them, and to help to make them possible. We are likely to have in our hands, before many months, the final and authoritative record of his life and of his work. It will be a book worth waiting for, and it will be, even in these hard times, a book worth buying.

Meanwhile, for all who love to read of surgery -and who does not?- there are two admirable lectures by Keen of Philadelphia, entitled "Before and After Lister." They were given to the United States Army Medical School a few weeks ago, and are published in Science, June II and I8. They have much to say of military surgery, past and present, and they say it very well. There is also a very striking article in the Times of June 28 , on "Wounds and Blood-poisoning," and on the present work of Sir Almroth Wright at Boulogne. The lectures and the article, between them, give us a good insight into the progrès en spirale of surgery, from 1865 to $19{ }^{1} 5$.

\section{NOTES.}

IT was announced on July 5 that Admiral of the Fleet Lord Fisher of Kilverstone had been appointed chairman of the Inventions Board established to assist the Admiralty in co-ordinating and encouraging scientific effort in relation to the requirements of the Naval Service. The arrangements for the organisation of the Board have now been completed. It will comprise :- (a) A Central Committee; $(b)$ a Panel of Consultants composed of scientific experts who will advise the main Committee on questions referred to them. The Central Committee will consist of :Lord Fisher of Kilverstone, G.C.B., O.M. (president), Sir J. J. Thomson, O.M., F.R.S., Hon. Sir C. A. Parsons, K.C.B., F.R.S., Dr. G. T. Beilby, F.R.S. The Consulting Panel will comprise the following list, which will be added to from time to time as necessary :-Prof. H. B. Baker, F.R.S., Prof. W. H. Bragg, F.R.S., Prof. H. C. H. Carpenter, Sir William Crookes, O.M., F.R.S., Mr. W. Duddell, F.R.S., Prof. Percy Frankland, F.R.S., Prof. Bertram Hopkinson, F.R.S., Sir Oliver Lodge, F.R.S., Prof. W. J. Pope, F.R.S., Sir Ernest Rutherford, F.R.S., Mr. G. Gerald Stoney, F.R.S., Hon. R. J. Strutt, F.R.S. The Board is accommodated temporarily in the Whitehall Rooms, Hotel Métropole, Whitehall Place, S.W., but at an early date (which will be announced in due course) it will be transferred to permanent offices at Victory House, Cockspur Street, S.W. Communications should be addressed to the secretary, Board of Invention and Research.

$$
\text { NO. } 2386 \text {, VOL. 95] }
$$

WE regret to announce the death in action on the western front, on Saturday, July Io, of Lieut. Ernest Lee, a young botanist of considerable promise, who had already published some excellent work, notably a paper in IgII on leaf-fall. Lieut. Lee obtained a national scholarship in 1906, and while at the Royal College of Science, South Kensington, was both Marshall scholar and Forbes medallist. He was an associate of the Royal College of Science and a fellow of the Linnean Society. In rgro he became assistant lecturer in the botanical department at the Birkbeck College, London, and in 1913 went to the University of Leeds as a lecturer in agricultural botany. He there became a member of the Leeds O.T.C., and obtained a commission in the Duke of Wellington's Regiment soon after war broke out. In the autumn of 1914 he married Miss H. S. Chambers, lecturer in botany at the Royal Holloway College. Lieut. Lee was killed instantaneously by a bullet while with his guns, and he will be greatly regretted by all who knew him or his work.

LAST week we recorded with regret the death, at the age of twenty-seven, of Mr. H. S. Bion, assistant superintendent of the Geological Survey of India. Mr. Bion was born in India, and was educated at the School for the Sons of Missionaries at Yvesdon House, Blackheath, and at University College, London. His university career was a distinguished one. In 1905 he obtained the university scholarship in geology, and in 1906 the Morris geological prize. In $\mathrm{I} 908$ he took the degree of B.Sc. in the University of London, obtaining first-class honours in geology. In IgIr he was elected a fellow of the Geological Society. In February, Igrr, he joined the Geological Survey of India, and in the following November he was appointed curator of the museum and lecturer in the Presidency College, Calcutta. His work in the field was chiefly in Burma and Kashmir, and he did particularly valuable work in the latter area, especially among the Carboniferous rocks. His marked ability, his unselfish character, and scientific enthusiasm, endeared him to all with whom he came in contact, and his untimely death is deeply regretted by his former teachers in this country, his colleagues of the Indian Survey, and his numerous friends.

$\mathrm{By}$ the death of Mr. R. W. Raper, fellow, vicepresident, and bursar of Trinity College, the University of Oxford has suffered a serious loss. For some time his health had been failing, but the news of his sudden decease has come as a shock to his friends in Oxford, who had seen him walking about as usual up to within a very recent period. Mr. Raper was one of the best known and most highly respected of Oxford residents. His services to his college were of great value. The combination of clear-headed business aptitude, firmness in action, and humorous but not unsympathetic methods of dealing with difficult situations made him an almost ideal college bursar. Countless undergraduates have good cause to remember his generous friendship and refined hospitality. As a promoter of public interests he did a great work, both in his University and in his paternal home at Malvern. Oxford holds in especial gratitude his 